\title{
PRODUCTION OF PUMPKIN POWDER AND ITS UTILIZATION IN BAKERY PRODUCTS DEVELOPMENT: A REVIEW
}

\author{
Sudipta Das $^{1}$, Soumitra Banerjee ${ }^{2}$ \\ ${ }^{1}$ Department of Food Technology, Techno India University, Salt Lake, Sector V, Kolkata 700091, West Bengal, India \\ ${ }^{2}$ Department of Food Technology, Techno India, Salt Lake, Sector V, Kolkata 700091, West Bengal, India
}

\begin{abstract}
Pumpkin covers a wide number of species of the family Cucurbitaceae, most of them with actual or potential economic value. Dehydration of pumpkin for producing pumpkin powder can be a useful technique to preserve the pumpkin and obtain new processed food products from dehydrated pumpkin. The review focused on production of pumpkin powder by various drying techniques and incorporation of pumpkin powder in various bakery products as a replacement of wheat flour and also fortification of phytochemicals. The review also focused on physico chemical analysis of the pumpkin powder and pumpkin based bakery products and sensory analysis of the pumpkin based products. The replacement level of wheat flour by pumpkin flour in various bakery products determined by various researcher also focused in this review. The researchers reported that increasing the pumpkin flour concentration had an adverse effect on sensory analysis and colour. The researcher reported that pumpkin flour with low to medium concentration was found to be more acceptable from sensory point of view and thereafter sensory score was reduced. Adding more pumpkin powder increased the level of carotene in the bakery products. Phytochemicals were increased with increasing pumpkin flower concentration in bakery products.
\end{abstract}

Keywords: Pumpkin powder, $\beta$-carotene, cookie, cake, physiochemical analysis.

\section{INTRODUCTION}

Pumpkins are extensively grown in tropical and subtropical countries where it traditionally consumed as freshly boiled and steamed or as a processed food items such as soup or curry. Pumpkin is high in $\beta$-carotene, which gives its yellow or orange color [1]. $\beta$-carotene in plants that have pleasant yellow-orange color is a major source of vitamin $A[2]$. Consumption of foods containing carotene helps in prevention of eye disorders, cancer and skin diseases [3]. Incorporation of $\beta$-carotene rich foods in diets is the best measure to improve vitamin A nutrition of individuals to overcome the problems and diseases caused by Vitamin A Deficiency (VAD)[4,5].

Wheat has been used in a variety of food products such as bread, biscuits, cakes,[6,7] .In recent years, bakery and confectionary products are fortified with various nutrients to enrich them to become a complete food with all necessary nutrients. The base material used for the preparation of bakery and confectionary products i.e. wheat flour contains a limited amount of $\beta$-carotene which is considered as precursor of vitamin A which is available in variety of fruits and vegetables[8,9].Pumpkin powder can be use as the concentrated source of $\beta$-carotene in bakery and confectionary products. Pumpkin powder also rich in various phytochemicals which are very nutritious to us. This flour could be used due to its flavour, sweetness, deep yellow-orange color and considerable amount of dietary fiber.

The objective of this review is to give the overview of pumpkin powder production and utilization of pumpkin powder as a replacement of wheat flour in various bakery products. This review also focused on the replacement level of pumpkin flour, analysis of the pumpkin flour and pumpkin flour blended bakery products.

\section{PREPARATION OF RAW MATERIAL}

Pongjanta et al.,2006[7] reported that pumpkins were cut into $2 \times 3$ inches pieces and peeled. Bhat and Bhat ,2013 [10]reported that pumpkins were washed, peeled and manually cut into $2 \times 3$ inches pieces. Kulkarni and Joshi, 2012[11] reported that they cut pumpkins into $10 \mathrm{~mm}$ size cubes. El-Demery M.E.,2011[12] reported that pumpkin pieces were cut into slices of $2-3 \mathrm{~mm}$ thickness using a slicer.

\section{PRETREATMENT BEFORE DRYING}

Pretreatment such as blanching, dip in chemical solution e.t.c is very important step before drying to inactivate enzyme activity, microbial activity. Kulkarni and Joshi, 2012[11] applied blanching of pumpkins at $94^{\circ} \mathrm{C}$ for 2 minutes and sulphitation carried out in $500 \mathrm{ppm}$ solution of $\mathrm{K}_{2} \mathrm{~S}_{2} \mathrm{O}_{3}$ prior to drying. Pongjanta et al.,2006[7] reported that they soaked pumpkin in $0.1 \%$ citric acid solution for 15 minutes. El-Demery M.E.,2011[12] reported that pumpkin pieces were soaked in $0.2 \%(\mathrm{w} / \mathrm{v})$ sodium metabisulphite for 45 minutes. 


\section{PRODUCTION OF PUMPKIN POWDER BY}

\section{VARIOUS DRYING TECHNOLOGIES}

Pumpkin powder is made by dehydration techniques. Many researcher applied various drying technique such as tray drying, vacuum drying, cabinet drying, oven drying e.t.c to achieve pumpkin powder.

Pongjanta et al.,2003[13] revealed that pumpkin powder produced by juice extraction and cabinet drying then ground with pin mill and sifted through an 80 mesh sieve was cheap to produce, of good quality and easy to use as a $\beta$ - carotene supplement in food products.

Pongjanta et al.,2006[7] applied tray drying technology to the pumpkin residue which was obtained after juice extraction for production of pumpkin powder. They dried pumpkin residue at $65^{\circ} \mathrm{C}$ for 8 hours. The dried pumpkin ground and sifted through an 80-mesh sieve by Cycrotex sample mill.

Kulkarni and Joshi, 2012[11] applied vacuum drying technique and they applied drying at $80^{\circ} \mathrm{C}$ and $700 \mathrm{~mm} \mathrm{Hg}$ vacuum.

El-Demery M.E.,2011[12] dried pumpkin slices in hot air oven at $60^{\circ} \mathrm{C}$ for 24 hours . The dried pumpkin slices was grounded then flour was passed through a mesh sieve of size $0.25 \mu \mathrm{m}$ at14000 rpm.

\section{PROXIMATE ANALYSIS OF PUMPKIN POWDER}

Proximate analysis of the pumpkin powder measured by various researcher listed in Table1.Moisture percentage of the pumpkin powder was around $6 \%$ which is very low. $\beta$ carotene content and carbohydrate content of the powder was around $7.30 \mathrm{mg} / 100 \mathrm{gm}$ and $78.7 \%$ respectively. Pongjanta et al.,2006[7] reported that the water activity of the powder was $0.24 \pm 0.02$ which was relatively low and also safe from growth of microorganisms. Ash percentage was high and it was about $7.24 \%$. Protein percentage was low (3.73) which was reported both Bhat and Bhat,2013[10] and Pongjanta et al.,2006[7].The report of El-Demery M.E.,2011[12] showed that pumpkin flour was lower in moisture $(10.64 \%)$ and higher in protein, fat, ash, fiber and carbohydrate content than pumpkin pulp. This result was similar to Pongjantat et al., (2006)[7].

FP-Fresh Pumpkin

PP-Pumpkin Powder

Table1: Physiochemical analysis of fresh pumpkin and pumpkin powder

\begin{tabular}{|l|l|l|l|l|l|l|}
\hline $\begin{array}{l}\text { Analysis } \\
\text { of FP } \\
\text { and PP }\end{array}$ & \multicolumn{2}{|l|}{$\begin{array}{l}\text { Bhat and } \\
\text { Bhat,2013 }\end{array}$} & \multicolumn{2}{|l|}{$\begin{array}{l}\text { Pongjanta } \\
\text { al.,2006 }\end{array}$} & \multicolumn{2}{l|}{$\begin{array}{l}\text { El- } \\
\text { Demery } \\
\text { M.E.,2011 }\end{array}$} \\
\cline { 2 - 7 } & F P & PP & F P & PP & F P & PP \\
\hline MC( \%) & 87.3 & 6.01 & 84.32 & $6.01 \pm$ & 89. & 10. \\
& 0 & & \pm 3.75 & 1.47 & 65 & 64 \\
\hline
\end{tabular}

\begin{tabular}{|l|l|l|l|l|l|l|}
\hline $\begin{array}{l}\text { Crude } \\
\text { Fat(\%) }\end{array}$ & 1.43 & 1.32 & $\begin{array}{l}1.45 \pm \\
0.50\end{array}$ & $\begin{array}{l}1.34 \pm \\
0.64\end{array}$ & $\begin{array}{l}0.5 \\
6\end{array}$ & $\begin{array}{l}1.2 \\
5\end{array}$ \\
\hline $\begin{array}{l}\text { Protein( } \\
\%)\end{array}$ & 1.30 & 3.73 & $\begin{array}{l}1.29 \pm \\
0.43\end{array}$ & $\begin{array}{l}3.74 \pm \\
0.68\end{array}$ & $\begin{array}{l}1.2 \\
1\end{array}$ & $\begin{array}{l}9.6 \\
9\end{array}$ \\
\hline Ash(\%) & 1.25 & 7.23 & $\begin{array}{l}1.26 \pm \\
0.32\end{array}$ & $\begin{array}{l}7.24 \pm \\
0.79\end{array}$ & $\begin{array}{l}1.5 \\
0\end{array}$ & $\begin{array}{l}6.1 \\
3\end{array}$ \\
\hline $\begin{array}{l}\text { Crude } \\
\text { Fiber(\%) }\end{array}$ & 1.16 & 2.91 & $\begin{array}{l}1.17 \pm \\
0.08\end{array}$ & $\begin{array}{l}2.90 \pm \\
0.47\end{array}$ & $\begin{array}{l}1.8 \\
0\end{array}$ & 3.2 \\
\hline $\begin{array}{l}\text { Carbohy } \\
\text { drate(\%) }\end{array}$ & 10.5 & 78.7 & $\begin{array}{l}10.51 \\
\pm 1.08\end{array}$ & $\begin{array}{l}78.77 \\
\pm 5.42\end{array}$ & 6.9 & 71. \\
\hline $\begin{array}{l}\beta- \\
\text { carotene } \\
(\mathrm{mg} / 100\end{array}$ & 2.44 & 7.30 & $2.43 \pm$ & $7.29 \pm$ & - & 03 \\
gm) & & & 1.14 & 3.82 & & \\
\hline
\end{tabular}

\section{PREPARATION OF VARIOUS BAKERY}

\section{PRODUCTS FROM PUMPKIN POWDER}

Pongjanta et al.,2006[7] prepared five types of bakery products such as sandwich bread, sweet bread, butter cake, chiffon cake, and cookies from pumpkin powder by substituting wheat flour. Kulkarni and Joshi, 2012[11] prepared biscuits from pumpkin powder by replacing of wheat flour. Bhat and Bhat,2013[10] prepared cake from pumpkin powder. El-Demery M.E.,2011[12]prepared toast bread from pumpkin flour by substituting wheat flour.

\section{FORMULA USING TO PREPARE PUMPKIN}

\section{BASED BAKERY PRODUCTS}

Bhat and Bhat ,2013[7] reported that the cakes were prepared according to the method described by Ceserani and Kinton,1995[14]. The wheat flour was substituted with different percentages of pumpkin powder for the preparation of cake. The fat and sugar were creamed together until fluffy (double its size) in a stainless steel bowl followed by addition of skimmed milk. The sieved flour with baking powder and baking soda was folded into the mixture gradually with a metal spoon. When all the mixture flour is mixed, the remaining liquid is added. The batter was then placed in containers lined with paper and was baked in a pre-heated oven at $160^{\circ} \mathrm{C}$ for 30 minutes. After baking the cakes were cooled and packed air tight in high density polythene (HDPE) and kept in refrigerator for storage.

\section{Recipe of the Cake \\ Sugar-100gm \\ Butter-50gm \\ Skimmed milk- $40 \mathrm{ml}$ \\ Baking powder $-3 \mathrm{gm}$ \\ Baking soda $-2 \mathrm{gm}$ \\ Water $-100 \mathrm{ml}$ \\ Wheat flour $-100 \mathrm{gm}$}

Kulkarni and Joshi, 2012[11] reported that the biscuits were made using the standard recipe consisting of refined wheat flour 100gm, sugar $50 \mathrm{gm}$, fat $60 \mathrm{gm}$, sodium bicarbonate 0.5 gm, custard powder $2 \mathrm{gm}[15]$. Baking was carried out at $175^{\circ} \mathrm{C}$ for 12 minutes. 
Pongjanta et al.,2006[7] reported the standard formula of the pumpkin based bakery products were as follows:

1. Sandwich Bread: $100 \%$ wheat flour; and $0.5 \%$ bread improver, $4.45 \%$ skim milk powder, $1 \%$ dried yeast, $62.5 \%$ water, $4 \%$ sugar, $1.65 \%$ salt, and $6 \%$ shortening pumpkin powder was substituted as $\%$ of wheat flour as $\%$ of wheat flour.

2. Sweet Bread: $75 \%$ wheat flour, $25 \%$ all purpose flour; and $0.7 \%$ bread improver, $44 \%$ fresh milk, $1.6 \%$ dry yeast, $16 \%$ egg, $14.8 \%$ sugar, $1.25 \%$ salt, and $16 \%$ butter pumpkin powder was substituted as $\%$ of wheat flour as $\%$ of wheat flour.

3 Butter Cake: $100 \%$ cake flour; and 5\% corn flour, $0.8 \%$ baking powder, $0.8 \%$ vanilla, $112.5 \%$ sugar, $0.4 \%$ salt, and $113.5 \%$ butter pumpkin powder was substituted as $\%$ of wheatflour as $\%$ of cake flour.

4. Chiffon Cake: $100 \%$ cake flour; and $8 \%$ milk powder, $4 \%$ baking powder, $0.2 \%$ vanilla, $80 \%$ sugar , $1 \%$ salt, $100 \%$ egg yolk, $170 \%$ egg white, $75 \%$ water, $50 \%$ rice oil, $0.5 \%$ cream of tartar and $90 \%$ sugar pumpkin powder was substituted as $\%$ of wheat flour as $\%$ of cake flour.

5. Cookies: $100 \%$ all-purpose flour; and $8.9 \%$ skim milk powder, $1.4 \%$ baking powder, $0.6 \%$ salt, $61.5 \%$ margarine, $18.5 \%$ egg, $61.5 \%$ sugar and $16.6 \%$ water pumpkin powder was substituted as $\%$ of wheat flour as \% of all-purpose flour, The preparation methods for the bakery products were adopted from Pongjanta ,2002[16].

El-Demery M.E.,2011[12] prepared toast bread from pumpkin flour by following formula:

\section{Preparation of Toast Bread}

Flour blends were baked using the straight-dough method according to Chauhan et al.,(1992)[17] with little modification wheat flour were substituted by pumpkin flour. The baking formula was $500 \mathrm{~g}$ of flour blend, $9 \mathrm{~g}$ of compressed baker'syeast, $5 \mathrm{~g}$ of $\mathrm{NaCl}, 13 \mathrm{~g}$ of cane sugar, $10 \mathrm{~g}$ of vegetable shortening and approximately $280 \mathrm{ml}$ of water. All the ingredients were mixed in a Kenwood mixer (ModelA907D) for $3.5 \mathrm{~min}$. The dough were fermented for $90 \mathrm{~min}$ at $28 \pm 1^{\circ} \mathrm{C}$, then punched, scaled to $250 \mathrm{~g}$ dough pieces, proofed for $90 \mathrm{~min}$ at $30^{\circ} \mathrm{C}, 85 \%$ relative humidity and baked at $250^{\circ} \mathrm{C}$, for $30 \mathrm{~min}$.

\section{LEVEL OF SUBSTITUTION OF PUMPKIN POWDER WITH WHEAT FLOUR}

Pongjanta et al.,2006[7] substituted 10,20,30,40 and 50\% pumpkin powder for preparation of cakes and cookie. Kulkarni and Joshi, 2012[11] replaced wheat flour with pumpkin powder at different levels viz. 0, 2.5, 5.0 7.5 and $10 \%(\mathrm{w} / \mathrm{w})$ in the standard formulation of biscuits. Bhat and Bhat,2013[10] replaced 10,20 and 30\% pumpkin powder for production of cakes. El-Demery M.E.,2011[12] reported that they substituted 5,10,15 and $20 \%$ wheat flour with pumpkin flour.

\section{SENSORY QUALITIES OF PUMPKIN BLEND BAKERY PRODUCTS}

Kulkarni and Joshi, 2012[11] reported that amount of force required to bite the biscuit increased with concentration of pumpkin powder. When the concentration of powder was highest the hardness of the biscuits was highest, i.e. $3263 \mathrm{~g}$. Similarly, increasing the replacement level of refined wheat flour with pumpkin powder, the amount of force required to give first crack on the biscuit while breaking i.e. fracturability also increased. When the replacement level of refined wheat flour with pumpkin powder was increased to $10 \%$ the fracturability of biscuit increased to $1.74 \mathrm{~mm}$. Kulkarni and Joshi, 2012[11] also reported that biscuits made with $2.5 \%$ pumpkin powder scored maximum number in all sensory parameters viz. colour, flavor ,texture, taste and appearance given by the panelists.

Pongjanta et al.,2006[7] reported that Substituting a portion of wheat flour with pumpkin powder in sandwich bread, sweet bread, and cookies were acceptable at $10 \%$ level and $20 \%$ in butter cakes and chiffon cake. Further increase in the substitution level would affect color, volume and overall acceptability of the products.

El-Demery M.E.,2011[12] reported that 5 and $10 \%$ replacement in toast bread showed highest scored in odor, colour, texture and overall acceptability. The color of the toast bread was significantly affected $(\mathrm{P}<0.05)$ by the addition of pumpkin flour, but the color of $15 \%, 20 \%$ substitution of the pumpkin flour, toast bread showed a significant decrease $(\mathrm{P}<0.05)$.

\section{PHYSIOCHEMICAL ANALYSIS OF} PUMPKIN BLEND BAKERY PRODUCTS

Bhat and Bhat,2013[10] reported that with the incorporation of pumpkin powder for preparation of cake moisture, crude fiber, ash and $\beta$-carotene increased where as crude protein, crude fat and carbohydrate content decreased. Pongjanta et al.,2006[7] also reported that $\beta$-carotene percentage increase with increasing percentage of $\beta$-carotene incorporation. The products were generally high in fat and carbohydrate and lower in fiber. The use of pumpkin powder to substitute wheat flour in the baked products would increase the level of vitamin A. Kulkarni and Joshi, 2012[11] also reported same things on pumpkin blend biscuits. They also reported that during baking the optimum moisture could not retained in the biscuit as the carbohydrate content was increased due to the addition of pumpkin powder to replace the refined wheat flour. Moisture content, protein content was lower and ash, fiber content was higher in optimized sample than control sample. The minerals such as calcium, phosphorous and iron were more in the optimized biscuit sample as compared to the control sample and fat percentage remain same with respect to control. El-Demery M.E.,2011[12] reported that moisture, fat, ash percentage was increased with increasing the replacement level with respect to control. Carbohydrate and protein percentage of replacement toast bread was decreased when compared to control. 


\section{CONCLUSION}

This study revealed the effect of replacement of refined wheat flour with pumpkin powder on the textural and sensory qualities of bakery products. The pumpkin powder could be very well utilized to prepare the bakery products. This study also revealed that pumpkin powder significantly enhances $\beta$-carotene content and other phytochemicals in supplemented bakery products. The substituted products had high energy content. Pumpkin powder with lower concentration was found to be the optimum for replacement of wheat flour for production of pumpkin based bakery products.

\section{REFERENCES}

[1]. Bhaskarachary, K., Ananthan, R. and Longvah, T. 2008. Carotene content of some common (cereals, pulses, vegetables, spices and condiments) and unconventional sources of plant origin. Food Chemistry 106: 85-89.

[2]. Lee, F.A. 1983. Basic Food Chemistry.AVI Publisher, Westport.

[3]. Bendich, A. 1989. Carotenoids and the immune response. Journal of Nutrition 119: 112-115.

[4]. Chandrashekhar, U. and Kowsalya, S. 2002. Provitamin A content of selected South Indian Foods by high performance liquid chromatography. Journal of Food Science and Technology 39(2): 183-187.

[5]. Siems, S., Wiswedel, I., Salerno, C., Crifo, C., Augustin, L.S., Langhans, C.D. and Sommerberg, O.2005. $\beta$-carotene breakdown products may impair mitochondrial functions - Potential side effects of high dose $\beta$-carotene supplementation. Journal Nutritional Biochemistry 16: 385397.

[6]. Lee, C. H., Cho, J. K., Lee, S. J., Koh, W., Park, W. and Kim, C. H. 2002. Enhancing $\beta$-carotene content in Asian noodles by adding pumpkin powder. Cereal chemistry 79 (4): 593-595.

[7]. Pongjanta, J., Naulbunrang, A., Kawngdang, S., Manon, T. and Thepjaikat, T.2006. Utilization of pumpkin powder in bakery products. Songklanakarin Journal of Science and Technology 28 (1): 71-79.

[8]. Tee, E.S. and Lim, C.L. 1991. Carotenoids composition and content of Malaysian vegetables and fruits by AOAC and HPLC methods. Food Chemistry 41, 309-339.

[9]. Olson, J. A. 1989. Provitamin A function of carotenoids: the conversion of $\beta$-carotene into vitamin $A$. Journal of Nutrition 119: 105-108.

[10]. Bhat ,M.A. and Bhat, A.2013.Study on PhysicoChemical Characteristics of Pumpkin Blended Cake, Food Processing \& Technology 4(9) :1-4.

[11]. Kulkarni, A.S. and Joshi, D.C.2013. Effect of replacement of wheat flour with pumpkin powder on textural and sensory qualities of biscuit, International Food Research Journal 20(2): 587-591.

[12]. El-Deremy ,M.E.2011. Evaluation of physico-chemical properties of toast breads fortified with pumpkin(Cucurbita moschata) flour.

[13]. Pongjanta, J., Jomduang, S. and Panomwan, N.A., Ayuttaya,R. 2003. Effect of processing and drying treatment on quality of pumpkin powder. Food J. 33:68-76.
[14]. Cesarani, V., Kinton, R. 1995 .Practical cookery, 8th edn. Hodder and Stonghton, London.

[15]. Kamaliya, M. K. and Kamaliya, K.B. 2001. Baking Science and Industries. 1st Edn. Vol. I \& II.

[16]. Pongjanta, J. 2002. Cereal Product Technology LaboratoryManual. Lampang Agricultural Research and Training Center, Rajamangala Institute of Technology. Lampang. Thailand.

[17]. Chauhan G.S., Zillman R.R., Eskin NA.M. 1992. Dough mixing and bread making properties of quinoawheat flour blends. Int J Food Sci Technol 27: 701-705. 